\title{
ENTERPRISE FINANCIAL CHARACTERISTICS AND CORPORATE SOCIAL RESPONSIBILITY COSTS OF OIL AND GAS BUSINESSES IN NIGERIA
}

\section{Rapheal Oluchukwu Ugbor ${ }^{*}$}

Department of Accountancy, Enugu State University of Science and Technology, Enugu, Nigeria, Email: raphngo2003@yahoo.com

\section{Oliver Ikechukwu Inyiama}

Department of Accounting, Covenant University Ota, Ogun State, Nigeria, E-mail: oliver.inyiama@covenantuniversity.edu.ng

\section{Cordelia Onyinyechi Omodero}

Department of Accounting, Covenant University Ota, Ogun State, Nigeria, E-mail: cordeliaomodero@yahoo.com

\section{Ethel Chinakpude Inyiama}

Department of Accountancy, Enugu State University of Science and Technology, Enugu, Nigeria, Email: ethel.inyiama@yahoo.com

\section{(Received: September 2021; Accepted: November 2021; Published: December 2021)}

Abstract: This work evaluated the effect of entity characteristics on company social responsibility costs of oil and gas firms in Nigeria for 2010 - 2019. The independent variables of the study and measures of firm characteristics are total assets, total sales, financial leverage and firm age while the independent variable is corporate social responsibility. A sample of three firms was selected out of a population of eleven oil and gas businesses on the Nigeria Stock Exchange during the period. Supporting data were obtained from the selected firms and analyzed using multiple regression analysis. Findings from the analysis suggest that both total assets and total sales positively and significantly affect the corporate social responsibility costs of the firms. It was also found that financial leverage positively and insignificantly affects the corporate social responsibility costs of the firms. Finding further reveals that firm age negatively and insignificantly affects corporate social responsibility costs of the firms. In the light of the findings, it was recommended that the firm managers should invest in assets especially long-term assets that will yield future streams of returns for their firms. This is because investment in assets improves production and promotes the corporate social responsibility performance of the firms. It was also recommended that the

${ }^{*}$ Corresponding author: Rapheal Oluchukwu Ugbor.E-mail: raphngo2003@yahoo.com

Copyright (C) 2021 The Author(s). Published by VGWU Press

This is an Open Access article distributed under the terms of the Creative Commons BY 4.0 license (Creative Commons - Attribution 4.0 International - CC BY 4.0) which permits unrestricted use, distribution, and reproduction in any medium, provided the original author and source are credited. 
Ugbor, R.O., Inyiama, O.I., Omodero, C.O., Inyiama, E.C., (2021)

Enterprise Financial Characteristics and Corporate Social Responsibility Costs of Oil and Gas Businesses in Nigeria

firm managers should promote their products through various product promotion channels as total sales boast firm profitability and promote corporate social responsibility performance. It was further recommended that the firm managers should increase the proportion of debts in their firms' capital structure. It was finally recommended that firm managers should use a modern approach while implementing their corporate social responsibility programs as opposed to the old style.

Keywords: Firm characteristics; corporate social responsibility costs; Oil and Gas firms; multiple regressions.

\section{Introduction}

Financial statements give data related to the organizations' financial position and financial execution. The data contains a couple of components that decide the organizations' financing tasks and speculation frameworks towards the firm presentation. These determinants are called firm attributes. A segment of these determinants is called financial qualities while others are called non-financial attributes (Sinthupundaja and Chiadamrong, 2015). Financial attributes are needed by firm partners like financial backers, lenders, and investors in making monetary choices. Partners might disregard to make precise and judicious monetary choices if financial statements uncovered by firms don't reflect the authentic execution and financial situation of a firm (Karakteristikleri, Hilesi and Yaklaşım, 2016).

Shuaibu (2020) says that firm qualities suggest the features which a particular firm posses that decide its functional activities. They are the principal determinants that impact an association's financial choices and various methodologies that the association gets. Observational examinations reveal a wide extent of mediators for firm attributes. The specific measures used depend upon the possibility of the examination and the financial region being thought of. For example, Fahimeh and Shokat (2015) recorded financial qualities to incorporate firm size, return on esteem, return on resources, esteem income extent, book-market esteem extent, overall revenue and financial influence. Basically, Valipour, Moradi and Farsi (2012) recognized firm attributes as working pay, firm size, bargain advancement, current extent, rapid extent and commitment extent. Additionally, Eric, Gong, Chagant and Meric (2012i) perceived financial qualities as current extent, record of offer turnover, stock turnover, fixed resources turnover, complete resources turnover, esteem extent, net revenue, return on resources, return on worth and yearly deals advancement rate. The current examination, regardless, got all out resources, complete deals, financial influence and firm age and surveyed their impact on the firm's societal obligation expenses of gasoline and fossil fuel businesses in Nigeria. 


\section{Clarification of the Problem}

The unfavorable result of activities of oil and gas firms on the climate of their host networks in Nigeria and the prerequisite for palatable remuneration of the networks has been a topic of conversation in Nigeria for a significant long time. Oil slicks and gas erupting have tainted, de-evaluated and destroyed the mangrove woods and water arrays of the Niger Delta of Nigeria, therefore causing authentic obliteration of its biodiversity all through the long haul.

These ecological contaminations and the carelessness of some oil and gas firms working in Nigeria compelled some host networks to establish youth advancements and equipped social affairs to checkmate the activities of the petrol and gas companies in the networks. This has achieved the vitalization of oil and gas workplaces, capturing and interrupting oil and gas creation in the country. This has in go led to lackluster showing and the inevitable extinction of some oil and gas firms in Nigeria. It is in perspective on this advancement that the analyst left on this examination to assess the effect of firm characteristics on corporate social responsibility costs of oil and gas companies in Nigeria.

\section{Aims of the study}

The main goal of the study is to evaluate the repercussion of firm characteristics on corporate communal responsibility costs of oil-and-gas firms in Nigeria. The fixed aims of the study are:

i. Evaluate the effect of total assets on corporate public responsibility costs of gas and oil firms.

ii. Examine the effect of total sales on corporate civic responsibility costs of gas and oil firms.

iii. Appraise the effect of financial leverage on corporate community-based responsibility costs of gas and oil firms.

iv. Ascertain the effect of firm age on firm social obligation costs of gas and oil firms.

\section{Review of related literature}

\subsubsection{Firm Characteristics}

Kogan and Tian (2012) communicated that firm attributes incorporate firm size, influence, liquidity, deals advancement, asset improvement and turnover. Firm Size has gotten prevailing in precise corporate money mulls over and has been comprehensively settled among the principal factors (Kioko, 2013). Sinthupundaja and Chiadamrong (2015) moreover assert that firm Size, improvement and age are viewed as huge firm brand name factors, which are frequently used to decide firm execution. 
Ugbor, R.O., Inyiama, O.I., Omodero, C.O., Inyiama, E.C., (2021)

Enterprise Financial Characteristics and Corporate Social Responsibility Costs of Oil and Gas Businesses in Nigeria

In trial examinations, different makers used different extents of firm qualities in their assessments. The specific measures got to depend upon the possibility of the examination and in like manner the monetary region being thought about. For example, Meric et al. (2012) in their examination of firm financial attributes of U.S and Japanese used current extent, record of offer turnover, stock turnover, fixed resources turnover, absolute resources turnover, esteem extent, net overall revenue, return on resources, return on worth and yearly deals advancement rate as extents of firm financial qualities. Basically, Fahimeh and Shokat (2015) used firm size, return on esteem, return on resources, esteem income extent, book-market esteem extent, net revenue, productivity and financial influence in their examination of the connection between financial attributes of firms in substantial assembling industry and stock returns in Tehran. Also, Sinthupundaja and Chiadamrong (2015) used a factor of advancement, size, and firm age to examine producing firms' qualities and financial frameworks on the financial execution improvement of firms in Thailand. With the ultimate objective of this assessment, in any case, we got all our resources, all-out deals, financial influence and firm age as firm attributes.

\subsubsection{Total Assets}

Maggina and Tsaklanganos (2012) portray resources as financial resources of a firm expected to benefit the association's future tasks. Resources of a business undertaking are a vital piece of business activities that work related to various segments of liabilities and worth in the overall business tasks. The specific sorts of resources that a firm will require will depend upon the possibility of its business development like assembling, marketing or organization. There are various techniques for characterizing resources like significant and immaterial, moneyrelated and non-financial, current and non-current. Sloan (2004) regardless, assembled resources into, current, non-current and immaterial assets.

Singh and Pandey (2008) characterize non-current resources for incorporate, land, building, plant, apparatus, furniture, fitting, office gear, etc which are not procured with the ultimate objective of marketing, yet for functional reasons. Scott (2003) similarly communicates that non-current resources are those resources that can't be changed over into cash during a period of maintaining a business. In this manner, they are those resources that will benefit the firm for more than one business cycle (a year) and are ordinarily communicated in the decree of the financial situation of firms at true (cost of procurement) less accumulated deterioration. Then again, current resources such as cash/bank holding; stock and customers' owing are seen as vital segments of the company's complete resources. A company's interest in current resources like cash, bank stores, transient assurances, accounts receivables and 
Ugbor, R.O., Inyiama, O.I., Omodero, C.O., Inyiama, E.C., (2021)

Enterprise Financial Characteristics and Corporate Social Responsibility Costs of Oil and Gas Businesses in Nigeria

inventories are called working capital (Padachi, 2006). Current resources in a single trade can be a non-current resource in other businesses. For example, PCs that are made accessible to be bought are current resources in the records of the PC fabricating entities; comparative PCs are non-current resources in the documents of various organizations that get them for consumption underway (Peterson, 2002). The current, non-current and immaterial resources of a firm amassed are known as the absolute resources. The absolute resources as recorded on an ordinary announcement of the financial situation of a firm would incorporate cash and bank changes, stock, receivables and property, plants and equipment among others.

\subsubsection{Total Sales}

Kennon (2017) characterizes deals as the proportion of cash a business gained during the time period covered by the pay clarification which doesn't address the benefit of the business. The business pay figure is critical because a business ought to acquire cash to bring in cash. If an association has more pay, considering everything, it will make more benefit. For fire-up firms that are yet to make a benefit, the pay can a portion of the time fill in as a check of conceivable productivity later on. Kokemuller (2016) also portrays deals as a financial motor of a firm without which a firm can't obtain a benefit and stay pragmatic over the long haul. This is in light of the fact that a firm needs to bargain its things and make payments to legitimize the fixed and variable expenses caused to work the business.

Hand (2005) announces that business pay is a huge issue in every association in every space of industry since deals pay is the principal trades channel via which a company's fortune and advancement openings are changed over into quick assets. Various associations set forth certified endeavors to make their business pay; as such expanding their association's presentation. There are various limits that can impact the size of deal pay, both from a financial and non-financial perspective. As per the financial perspective, various things are acknowledged to impact deals pay, for example, financial expenses, a slice of the pie, monetary turn of events, esteem level, and others.

Absolute deals can simply be resolved as an all-out number of units sold copied by the expense per unit, this recommends that market cost and sum sold are among the critical determinants of all-out deals. Change sought after of thing or organization of a firm also changes the all-out deals of that firm, thusly request is the marker of deals advancement (Vijayakumar and Devi, 2011).

\subsubsection{Financial Leverage}

Enekwe, Agu, Ikechukwu and Eziedo (2014) express that financial influence is the extent of how much firms use worth and commitment to back their resources. It's 
Ugbor, R.O., Inyiama, O.I., Omodero, C.O., Inyiama, E.C., (2021)

Enterprise Financial Characteristics and Corporate Social Responsibility Costs of Oil and Gas Businesses in Nigeria

everything except an extent of commitment extent in a company's capital plan. A firm can back its speculations by commitment and worth; it may similarly use tendency capital. The speed of interest on commitment is fixed paying little heed to the company's speed of return on resources. The financial influence used by a firm is expected to get more on the fixed charges resources than their expenses. As commitment extent in a company's capital plan increments, financial influence similarly increments. The fundamental goal of a firm in utilizing financial influence is to build investors' benefit from speculation and under incredible monetary conditions. The work of financial influence in amplifying the appearance of the investors relies upon the suppositions that the fixed charges hold (like the development from financial foundations and various sources or debentures) can be gotten to a detriment lower than the company's speed of return on network resources. Ojo (2012) announces that organizations need higher commitment levels when expected earnings are higher because they can all the more promptly utilize the assessment decreases of commitment (being charge deductible expense). For some irregular commitment levels, the probability of causing the cost of financial difficulty or financial risk is lower at whatever point expected salaries are higher. Owalobi and Anyang (2013) recognize two kinds of influence, working influence and financial influence. Working influence is the usage of fixed expenses, the degree of which is characterized as the change of a company's income before interest and appraisal to change in deals. Financial influence then again is the presence of commitment in an association's capital development. From this time forward, a turned firm is the one that commits to its capital plan. The capital development of a firm can show up as $0 \%$ commitment, $100 \%$ worth; or $100 \%$ commitment, $0 \%$ worth; or $\mathrm{X} \%$ commitment, $\mathrm{Y} \%$ esteem. It is ordinary said that the most possible one in the veritable circumstance is $\mathrm{X} \%$ commitment and $\mathrm{Y} \%$ esteem. Firms' optimal commitment extent is controlled by a trade-off between the part 11 costs and obligation benefit of acquiring and it is refined precisely when the minor present worth of the evaluation on extra commitment is identical to the increment in the current worth of financial torment costs. Modigliani and Miller (1963) in the tradeoff theory verifies that the best financing mix concurs with the level of financial influence at which the benefits and expenses of commitment financing are all things considered changed. Expanding financial influence might engage a firm to build its value by benefitting from charge shields on commitment; higher financial influence might incite higher expected quick and circuitous financial difficulty costs, which decrease the association's worth (Ross et al., 2002). 


\subsubsection{Firm Age}

Shumway (2001) characterizes age as the time period during which a being or thing has existed. Accordingly, firm age is the amount of extended lengths of the fuse of the firm; despite the way that a couple of investigators acknowledge that posting age, should characterize the age of the firm. In like manner, posting age is more efficient since posting is a characterizing second in the association's life. Gitzmann (2008) in any case, a battle that as a real individual, a firm is brought into the world through consolidation thus, the tendency for the hour of joining as the meaning of the age of a firm. Yameen, et.al (2019) states that firm age represents the age of a firm at the time span of assessment. With the ultimate objective of this examination, we assessed firm age from the contrast between the hour of this assessment and the hour of fused. Keeping up with the presence of business for a long time span is hard thinking about that the firm should keep up with the idea of its things in connection with the consequences of its adversaries. Appropriately, a firm ought to be creative with its things and development to stay competitive in the business place.

Sorensen and Stuart (2000) in their Learning-By-Doing Theory, avow that, as firms create, they should have the alternative to learn. They can learn by doing or by putting resources into imaginative work; they can enroll HR and train their agents; and they can acquire from various firms in something almost identical as well as in various ventures. Chang, Gomes and Schorfheide (2002) comparably recommend that more prepared firms might benefit from their more important business experience, and along these lines have a more genuine degree of advancement innovation than more energetic firms. Pastor and Veronesi (2003), report that benefit and market-to-book extents decay with firm age as financial backers learn and vulnerability decreases. The impact of a company's age on firms' corporate social obligation practices is cloudy. For example, Simona and Veronika (2020) express that firm age and sexual direction assortment of sheets were not the parts influencing the corporate social responsiveness practice in the transportation and capacity industry of the Czech Republic. Then again, Zaid (2013) recommends that firm attributes, for instance, firm age have a positive and quantifiably basic relationship with corporate social duty openness in the non-financial space of Pakistan.

\subsubsection{Corporate Social Responsibility}

Simona and Veronika (2020) proclaim that the idea of corporate social duty is connected to having duties and making moves past their genuine commitments and business focuses. It covers monetary, social, natural, and charitable activities. A couple of firms' tasks are hazardous to the climate; thusly, the organizations will overall effectively lessen the impacts of its procedure on the host networks. Firms 
Ugbor, R.O., Inyiama, O.I., Omodero, C.O., Inyiama, E.C., (2021)

Enterprise Financial Characteristics and Corporate Social Responsibility Costs of Oil and Gas Businesses in Nigeria

have used ordinary and ecological resources and firms should, in pay for the use, treat and deal with the climate very well (Ong, Tho, Goh, Thai and Teh, 2016).

Corporate social duty could impact existing key business estimations. Then again, the idea and its application could be affected by firm attributes, similar to firm measure, age, organization of the executives, or firm financial execution. Corporate social obligation utilizations could cause extra expenses for the organizations and divert resources from more beneficial anticipated ventures. It may provoke a fleeting decrease in business execution. Then again, stakeholders' speculation prescribes that organizations should participate in incredible associations with all stakeholders and that corporate social obligation utilization could accelerate financial execution considering roundabout benefits (Simona and Veronika, 2020).

\subsection{Theoretical Framework}

\section{Edward Freeman (1984) Stakeholders' Theory}

This examination is secured on this theory in the context of the solid relationship existing between firm qualities and corporate social obligation costs.

\subsubsection{Stakeholders' Theory}

Edward Freeman propounded the Stakeholders' Theory in 1984. The theory expressed despite office speculation considers associations to be a game plan of relationship among shareholders and the board. Stakeholders' speculation considers associations to be a structure that obliges the interest of the owners just as the interests of various social occasions inside the climate in which the association works. The speculation fought that since associations can't work and exist in seclusion without relating with its close by climate then the interest of various stakeholders like delegates, customers, suppliers and host neighborhood be considered during the time spent crucial dynamic. Thus, the fundamental dispute of the speculation, as pointed by Lawal (2011), is that associations should increase the benefits of shareholders alone, yet furthermore, the assumptions for various stakeholders should be thought of. At last, the theory battled that for a firm to achieve powerful execution watching out, the agreeable relationship should exist between the firm and the stakeholders and the firm board should be tremendous and separated enough to oblige the premium of various stakeholders. The accomplice's theory proposed an expanded level of ecological care which makes the necessity for associations to loosen up their corporate wanting to incorporate the non-customary stakeholders like the authoritative adversarial get-togethers in solicitation to conform to changing social requests as in (Malarvizhi and Yadav, 2008). The primary worry of the stakeholders' speculation in corporate social duty bookkeeping is to address 
Ugbor, R.O., Inyiama, O.I., Omodero, C.O., Inyiama, E.C., (2021)

Enterprise Financial Characteristics and Corporate Social Responsibility Costs of Oil and Gas Businesses in Nigeria

the climate cost segments and valuation and its incorporation in the financial statements.

\subsection{Empirical Review}

A combination of investigates has been finished identifying with this space of study. A segment of these examinations was done in Nigeria while some were directed external the country. With an ultimate objective to discover what is as of now suspected about the subject, we present under the discoveries from these observational assessments.

\subsubsection{Total Assets and Corporate Social Responsibility Costs}

Onyali and Okafor (2018) led an assessment to find out the impact of firm qualities on corporate natural execution of recorded modern product firms in Nigeria. The autonomous components of the examination are the magnitude of the firm, productivity and period of existence while the outcome variable is waste administration cost. The examination got the ex-post facto research plan. An illustration of 11 modern product firms recorded on the Nigerian Stock Exchange was reviewed for the assessment. Auxiliary data were sourced from yearly reports and financial statements of the analyzed firms covering the hour of 2008-2017. The data assembled were analyzed utilizing Pearson connection coefficient and Multivariate Regression Analysis. At a 5\% level of significance, results from the assessment show that firm credits, specifically, firm size, productivity and firm age have a colossal and valuable result on natural execution assessed by waste administration cost. In the light of these discoveries, it was recommended that considering the need to acquire advantage and lift firm worth, mechanical product firms should resolve issues shared to natural administration by creating plans of action and procedures that will ensure ecological maintainability.

Uwalomwa (2011) explored the relationship between firms' qualities and the level of corporate social revelations in the Nigerian non-financial region from 2005 to 2009. The free factors of the assessment are firm size, return on resources and size of the audit firm while the dependent variable is corporate social openness. Basic inspecting technique was used to test a sum of 31 firms decided for this assessment subject to their level of market capitalization and direct financing. The picked firms are generally from the assembling space of the Nigeria economy. Content data examination procedure and scoring plan were used for estimating the level of corporate social exposure in the yearly report. Result demonstrates that a positive affiliation existed between firms' attributes and the level of corporate social revelation. The assessment recommended that standard-setting bodies should set up

150 S sciendo Journal of Legal Studies Volume 28 Issue 42/2021

ISSN 2457-9017; Online ISSN 2392-7054.

Web: publicatii.uvvg.ro/index.php/jls. Pages $142-162$ 
a corporate social-ecological revealing framework, in solicitation to work all good of corporate social revelations among recorded firms in the country.

Zaid and Nasiri (2018) explored the impact of firm qualities all well and the good of corporate social duty (CSR) detailing in Palestinian from 2013 to 2016. A sum of 33 non-financial firms was picked for the examination and optional data was acquired from the organizations covering the hour of the assessment. A board data relapse assessment was gotten to test the relationship between firm attributes and the level of CSR openness. It was seen after the examination that firm attributes, explicitly, firm size, productivity, firm age, have a positive and quantifiably basic relationship with CSR disclosure.

\subsubsection{Total Sales and Corporate Social Responsibility Costs}

Kaoje and Auwal (2020) examined the impact of deals and firm size on the maintainability announcing of oil and gas firms in Nigeria from 2004 to 2018. The examiner assigned a populace of 24 oil and gas firms having a critical influence in the upstream, most of the way, and downstream of the Nigerian oil and gas region. Six (6) of the organizations were picked for the assessment. Board relapse assessment was utilized to research auxiliary data got from yearly records and financial statements of the reviewed firms. It was seen after the data examination that firm qualities assessed with deals improvement, firm size, and influence applies a negative enormous impact, however, firm size applies a positive basic impact on supportability revealing and productivity of oil and gas firms in Nigeria. It was recommended in the light of the discoveries that oil and gas firms should consider a mix of normal stock, supported stock and held profit as a sort of capital plan than offering a tendency to commitment financing.

Kartiningsih (2020) inspected the impact of firm attributes on the benefit of food and drinks firms recorded in Indonesia from 2014 to 2018. Firm attributes were proxied by firm age, firm size, liquidity, and influence while benefit was proxied with return on deals. The assessment assigned all of the 12 food assortments and refreshment firms recorded in the Indonesia Stock Exchange during the period. Optional data were assembled from the organizations covering the period and researched utilizing realistic bits of knowledge and various relapse assessments. The result of the assessment suggests that firm age, firm size, liquidity, and influence have a basic and valuable result on the productivity of the organizations. In the context of this, it was recommended that the organizations should keep up with their resources, commitment resources, and all resources adequately and capably by utilizing experience staff that is data and all-around gifted with capacities to gain benefits for the organizations. 
Ugbor, R.O., Inyiama, O.I., Omodero, C.O., Inyiama, E.C., (2021)

Enterprise Financial Characteristics and Corporate Social Responsibility Costs of Oil and Gas Businesses in Nigeria

Onyali, Okerekeoti, Chinedu and Uchegbu (2020) examined the connection between firm attributes like firm size, benefit and financial influence with social obligation divulgence of recorded shopper stock firms in Nigerian. The examination accepted Ex-post facto research plan. An illustration of 20 purchaser items producing firms recorded on the Nigeria Stock Exchange was picked for the examination. Optional data were sourced from the dispersed yearly report of the picked firms. The content examination was used to evaluate corporate social obligation disclosure and different relapse assessment was used to find out the connection between friendly duty exposure and firm qualities. The result shows a solid positive connection between firm size; benefit; influence and corporate social duty disclosure. This assessment advocates for additional created corporate social duty disclosure as this will work on a more significant coordinated effort among firms and their stakeholders.

\subsubsection{Financial Leverage and Corporate Social Responsibility Costs}

Alodia and Atmadja (2018) inspected the impact of firm attributes and corporate organization on corporate social obligation and future firm execution. The free factors are firm-unequivocal qualities (productivity, influence, and size) and corporate organization (load upsize, load up autonomy, women directorate, and survey boards) Also the impact of CSR execution on the future execution of firms in the accompanying 1-3 time spans by mining region associations recorded on the Indonesia Stock Exchange in 2008-2017 was inspected. Standard Least Square (OLS) relapse with the sort of board data was used to separate the data assembled for the assessment. Results demonstrate that productivity, size, board size, board freedom, and women of the board are not related to CSR execution in the mining associations. Regardless, influence and audit sheets impact CSR execution in mining associations. CSR execution impacts future firm execution during the first period after the CSR execution of mining firms.

Yousra (2018) led an examination to evaluate the consequence of a couple of entity attributes on environmental information revelation of recorded firms in Egypt from 2007 to 2011. In solicitation to do the assessment, 45 most unique firms recorded in the Egyptian Stock Exchange were picked for the examination. Optional data covering the hour of the examination were assembled from the inspected firms. Distinctive relapse assessment was applied on the assembled data to test the invalid speculations figured. It was seen after the assessment that there is an unimportant connection uniting two components of organizations' qualities (Company Size and Financial Leverage) and Environmental Information Disclosure.

Hassan (2014) led an assessment to research the impact of firm attributes on the risk exposure nature of Egyptian firms. Utilizing an illustration of the Egyptian recorded firms for the hour of 2006-2010 (comprises of 135 perceptions), the study found that 
there is an improvement in all models of peril openness quality, and the risk data is significant and justifiable mostly, yet it is less same and certain. Delayed consequences of the real assessment moreover show that the firm size and influence level are the fundamental determinants of the risk divulgence quality.

\subsubsection{Firm Age and Corporate Social Responsibility Costs}

Zaid (2013) considered the impact of firm qualities all well and the good of corporate social duty (CSR) announced in Parkistan from 2013-2016. An aggregate of 33 nonfinancial firms recorded in Parkistan Stock Exchange was picked for the examination. Auxiliary data for the period 2013 to 2016 were accumulated from the tried firms. Board data relapse assessment was applied to the data to test the relationship between firm attributes and the level of CSR disclosure. Discoveries from the examination suggest that firm attributes, specifically, firm size, productivity, firm age, have a positive and quantifiably enormous relationship with CSR divulgence.

HeaJeong and Youngchan, (2020) used board data from 2010 to 2018 for 184 USrecorded firms and analyzed how the corporate social duty (CSR) and CSR threatening events (CSR AE) impact the corporate financial exhibition (CFP) and research the directing impact of firm age on the relationship among CSR and CFP. The result from the board data relapse assessment shows that firm age consequences for CFP emphatically regardless, it conversely coordinates the positive relationship between CSR and CFP. It was also seen that the impact of CSR on CFP is outstandingly weak for more prepared firms. It was suggested in context on the discoveries that more settled firms are more based on overseeing CSR AE and younger firms are urged to submit more to CSR works out.

Simona and Veronika (2020) analyzed the connection between firm qualities like entity periods of existence, magnitude, entity execution, plus sexual direction assortment of sheets including the utilization of a corporate civic duty idea in the Czech haulage and capacity sector. Statistics from Albertina's informational index and trade documentary were used for the assessment while Pearson's and Spearman's connection coefficient plus relapse examination were used to separate the data. Results from the examination suggest a quantifiably enormous connection linking firm magnitude, entity accounting execution, including the CSR tradition of businesses. Then again, firm age and sexual direction assortment of sheets are not the segments affecting CSR practice of the organizations. 


\subsection{Summary of Empirical Review}

The research inspections show that lone four (4) out of the twelve (12) considers studied were led in Nigeria while the leftover eight (8) were directed external Nigeria. This shows that more examinations are required in the country in solicitation to close the assessment opening. The assessments directed in Niger are by Uwalomwa (2011) who examined the relationship between firm attributes and the level of corporate social openings in the Nigerian non-financial region. Onyali and Okafor (2018) analyzed the impact of firm qualities on the corporate ecological execution of recorded firms in Nigeria. Onyali et al. (2020) explored the connection between firm size, benefit and financial influence with social duty openness of recorded purchaser items firms in Nigeria. Kaoje and Auwal (2020) evaluated the impact of deals and firm size on the maintainability announcing of oil and gas firms in Nigeria.

It might be moreover seen from the table that just one of the ten examinations was directed in the oil and gas region while the leftover nine assessments were led in various regions. This proposes that the oil and gas region requires more examinations in this space.

At long last, it is seen that none of the assessments cover 2019 subsequently creating a deferent that should be covered. It is in context on these assessment openings that we leave on this assessment to investigate the contribution of firm characteristics on enterprise social responsibility of gas and oil firms in Nigeria from 2010 to 2019.

\section{Methodology}

The research is an ex post facto study that gives a verifiable solution to examine issues, by applying existing statistics. Non-primary data were gathered from annual financial statements made public by listed gas and petroleum firms selected for the study period of $2010-2019$. The population of the study comprised the entire eleven (11) oil and gas firms were listed on the Nigeria Stock Exchange during the period. A sample of three (3) oil and gas firms were randomly selected from the population of eleven (11) oil and gas firms listed on the Nigeria Stock Exchange during the period. Disclosure of corporate social responsibility expenses in the annual financial statement was the criteria in selecting the firms.

The study models formulated from the variables are:

$\mathrm{CSRC}=\beta_{0}+\left(\beta_{1} \mathrm{TOA}+\beta_{2} \mathrm{TOS}+\beta_{3} \mathrm{FNL}+\beta_{4} \mathrm{FIA}\right)+\varepsilon$

Where:

CSRC $=$ Corporate Social Responsibility Costs.

TOA $=$ Total Assets

TOS $=$ Total Sales

$\mathrm{FNL}=$ Financial Leverage

154 Sciendo Journal of Legal Studies Volume 28 Issue 42/2021

ISSN 2457-9017; Online ISSN 2392-7054.

Web: publicatii.uvvg.ro/index.php/jls. Pages $142-162$ 
Ugbor, R.O., Inyiama, O.I., Omodero, C.O., Inyiama, E.C., (2021)

Enterprise Financial Characteristics and Corporate Social Responsibility Costs of Oil and Gas Businesses in Nigeria

$$
\begin{aligned}
& \text { FIA = Firm Age } \\
& \beta=\text { beta } \\
& \varepsilon=\text { error term }
\end{aligned}
$$

\begin{tabular}{|c|c|c|c|}
\hline Variable Name & Label & Description & $\begin{array}{l}\text { Data } \\
\text { Source }\end{array}$ \\
\hline $\begin{array}{l}\text { Corporate } \\
\text { Social } \\
\text { Responsibility } \\
\text { Costs }\end{array}$ & CSRC & $\begin{array}{l}\text { Corporate social responsibility is a concept } \\
\text { used to describe the compensations by a firm to } \\
\text { its host community as a result of the } \\
\text { environmental degradation caused by the } \\
\text { activities of the firm within the community, or } \\
\text { expenses incurred to reduce the harmful effect } \\
\text { of organizational activities to society. The costs } \\
\text { could be donations, scholarships, training, } \\
\text { wastes management, the establishment of } \\
\text { public utility infrastructures among others. }\end{array}$ & $\begin{array}{l}\text { Annual } \\
\text { Reports } \\
\text { and } \\
\text { Accounts }\end{array}$ \\
\hline Total Assets & TOA & $\begin{array}{l}\text { Assets are the economic resources of a firm that } \\
\text { are expected to generate future returns for the } \\
\text { organization. Total assets are the sum total of } \\
\text { current, non-current and intangible assets of the } \\
\text { firm. }\end{array}$ & $\begin{array}{l}\text { Annual } \\
\text { Reports } \\
\text { and } \\
\text { Accounts }\end{array}$ \\
\hline Total Sales & TOS & $\begin{array}{l}\text { Total sales or turnover is the amount of income } \\
\text { that a firm receives from selling products or } \\
\text { services from its normal business activity. }\end{array}$ & $\begin{array}{l}\text { Annual } \\
\text { Reports } \\
\text { and } \\
\text { Accounts }\end{array}$ \\
\hline $\begin{array}{l}\text { Financial } \\
\text { Leverage }\end{array}$ & FNL & $\begin{array}{l}\text { This is the proportion of borrowed funds in a } \\
\text { firm's capital structure. The higher the amount } \\
\text { of borrowed funds is the higher the financial } \\
\text { leverage of a firm. }\end{array}$ & $\begin{array}{l}\text { Annual } \\
\text { Reports } \\
\text { and } \\
\text { Accounts }\end{array}$ \\
\hline Firm Age & FIA & $\begin{array}{l}\text { Firm age is the length of life of a firm from the } \\
\text { date of incorporation until the period of time as } \\
\text { long as the firm still exists. }\end{array}$ & $\begin{array}{l}\text { Annual } \\
\text { Reports } \\
\text { and } \\
\text { Accounts }\end{array}$ \\
\hline
\end{tabular}

Table 1. Description of Variables

Source: Authors Compilation 2021.

\section{Data Analysis}

The raw data collected from the selected oil and gas firms analyzed were using descriptive statistics and multiple regression analysis and the results are presented in tables 2 and 3 respectively. 
Ugbor, R.O., Inyiama, O.I., Omodero, C.O., Inyiama, E.C., (2021)

Enterprise Financial Characteristics and Corporate Social Responsibility Costs of Oil and Gas Businesses in Nigeria

Table 2. Descriptive Statistics

\begin{tabular}{|l|l|l|l|l|l|}
\hline & CSRC & TOA & TOS & FNL & FIA \\
\hline Mean & 51727.22 & $2.55 \mathrm{E}+08$ & $1.86 \mathrm{E}+08$ & 0.390000 & 43.70370 \\
\hline Median & 4850.000 & 57850632 & $1.24 \mathrm{E}+08$ & 0.230000 & 49.00000 \\
\hline Maximum & 311586.0 & $1.08 \mathrm{E}+09$ & $5.26 \mathrm{E}+08$ & 3.720000 & 63.00000 \\
\hline Minimum & 1.000000 & 9278500. & 14138607 & 0.000000 & 21.00000 \\
\hline Std. Dev. & 89980.46 & $3.80 \mathrm{E}+08$ & $1.56 \mathrm{E}+08$ & 0.710379 & 14.97129 \\
\hline Skewness & 1.685493 & 1.449842 & 1.279202 & 4.027649 & -0.331049 \\
\hline Kurtosis & 4.555969 & 3.304038 & 3.161981 & 19.35122 & 1.468599 \\
\hline Jarque-Bera & 15.50766 & 9.563185 & 7.393122 & 373.7816 & 3.131509 \\
\hline Probability & 0.000429 & 0.008383 & 0.024809 & 0.000000 & 0.208930 \\
\hline Sum & 1396635. & $6.88 \mathrm{E}+09$ & $5.02 \mathrm{E}+09$ & 10.53000 & 1180.000 \\
\hline Sum Sq. Dev. & $2.11 \mathrm{E}+11$ & $3.76 \mathrm{E}+18$ & $6.32 \mathrm{E}+17$ & 13.12060 & 5827.630 \\
\hline Observations & 27 & 27 & 27 & 27 & 27 \\
\hline
\end{tabular}

Source: E-VIEW 8 Output 2021.

The descriptive statistics show that the mean value of the variables is, 51727.22, $2.555 \mathrm{E}+08,1.86 \mathrm{E}+08,0.390000$ and 43.70370 respectively for corporate social responsibility costs, total assets, total sales, financial leverage and firm age. Also the standard deviations of the variables are $89980.46,3.80 \mathrm{E}+08,1.56 \mathrm{E}+08,0.710379$ and 14.97129. This indicates high volatility for corporate social responsibility costs and firm age while the volatility for total assets, total sales and financial leverage was found to be moderate. The Jarque-Bera Statistics indicates that the data distribution is normally distributed judging from the level of significance which are all significant at 0.05 level of significance except for firm age. This result was also corroborated by the Skewness and the Kurtosis tests.

Table 3. Regression Analysis

Dependent Variable: CSRC

Method: Least Squares

Date: 05/31/21 Time: 17:59

Sample (adjusted): 430

Included observations: 27 after adjustments

\begin{tabular}{lllll}
\hline \hline Variable & Coefficient & Std. Error & t-Statistic & Prob. \\
\hline \hline C & -25250.77 & 18750.11 & -1.346700 & 0.1918 \\
TOA & 0.000129 & $2.60 \mathrm{E}-05$ & 4.983269 & 0.0001 \\
TOS & 0.000294 & $5.74 \mathrm{E}-05$ & 5.115067 & 0.0000 \\
FNL & 14567.83 & 10407.90 & 1.399689 & 0.1755 \\
FIA & -372.0584 & 498.3710 & -0.746549 & 0.4632 \\
\hline \hline
\end{tabular}


Ugbor, R.O., Inyiama, O.I., Omodero, C.O., Inyiama, E.C., (2021)

Enterprise Financial Characteristics and Corporate Social Responsibility Costs of Oil and Gas Businesses in Nigeria

\begin{tabular}{llll}
\hline R-squared & 0.922078 & Mean dependent var & 51727.22 \\
Adjusted R-squared & 0.907910 & S.D. dependent var & 89980.46 \\
S.E. of regression & 27305.78 & Akaike info criterion & 23.43316 \\
Sum squared resid & $1.64 \mathrm{E}+10$ & Schwarz criterion & 23.67313 \\
Log likelihood & -311.3477 & Hannan-Quinn criteria. & 23.50452 \\
F-statistic & 65.08308 & Durbin-Watson stat & 1.924163 \\
Prob(F-statistic) & 0.000000 & & \\
\hline \hline
\end{tabular}

Source: E-VIEW 8 Output 2021.

\section{Discussion of findings}

Discussion of Findings One: The regression table three above shows that the coefficient of total assets (TOA) is 0.000129 . Since total assets are significant at 0.05 level, we state that total assets (TOA) of firms positively and significantly affect corporate social responsibility costs of oil and gas firms in Nigeria during the period. The finding of this study is in agreement with Uwalomwa (2011), Zaid (2013), Hassan (2014), Zaid and Nasiri (2018), Onyali and Okafor (2018), Simona and Veronika (2020), Onyali et al (2020) and Kartiningsih (2020) but disagreed with the findings of Yousra (2018) and Kaoje and Auwal (2020). The outcome of this investigation is also in consonance with the Stakeholders' Theory developed by Edward Freeman in 1984. The theory states that since organizations cannot operate and exist in isolation without relating with their immediate environment and that the interest of other stakeholders like employees, customers, suppliers and host community should be considered in the process of strategic decision making. Firms with huge assets in an environment are likely to contribute to the host community not only as a way of giving back to society but also to protect their investments.

Discussion of Findings Two: The regression table equally reveals that the coefficient of total sales (TOS) in the regression model is 0.000294 which is positive and also significant at a 0.05 level of significance. Therefore, we state that the total sales (TOS) of firms positively and significantly affect the corporate social responsibility costs of oil and gas firms in Nigeria. The result of this study is in line with Uwalomwa (2011), Zaid (2013), Hassan (2014), Zaid and Nasiri (2018), Onyali and Okafor (2018), Simona and Veronika (2020), Onyali et al. (2020) and Kartiningsih (2020) but in contrast with the findings of Yousra (2018) and Kaoje and Auwal (2020). This result is consistent with the Stakeholders' Theory developed by Edward Freeman in 1984. The theory states that since organizations cannot operate and exist in isolation without relating with their immediate environment that the interest of other stakeholders like employees, customers, suppliers and host 
Ugbor, R.O., Inyiama, O.I., Omodero, C.O., Inyiama, E.C., (2021)

Enterprise Financial Characteristics and Corporate Social Responsibility Costs of Oil and Gas Businesses in Nigeria

community should be considered in the process of strategic decision making. Moreover, since corporate social responsibility is a self-regulated initiative by firms to contribute to societal goals, there is the likelihood that increased sales would be a driver for firms to contribute to society.

Discussion of Findings Three: It can also be observed from the regression table that the coefficient of financial leverage in the regression model is 14567.83 . This is positive, but not significant at a 0.05 level of significance. Therefore, we conclude that the financial leverage of firms is positively, but insignificantly associated with business social responsibility costs of gas and oil firms in Nigeria. This result is in consonance with Yousra (2018) and Kaoje and Auwal (2020) but disagreed with the findings of Onyali et al (2020) and Kartiningsih (2020). The result is also consistent with the Stakeholders' Theory developed by Edward Freeman in 1984. The theory states that since organizations cannot operate and exist in isolation without relating with their immediate environment that the interest of other stakeholders like employees, customers, suppliers and host community should be considered in the process of strategic decision making.

Discussion of Findings Four: The regression table further reveals that the coefficient of firm age (FIA) in the regression model is -372.0584. This is negative and insignificant at a 0.05 level of significance. Thus, we say that firm age (FIA) negatively and insignificantly affected business societal responsibility costs of oiland-gas firms in Nigeria during the period. From the analysis, increases in firm age decrease corporate social responsibility of firms. Probably the older firms feel that they have arrived and therefore needless to promote their image in the society. The result of the study is in line with Yousra (2018) which found a negative association between firm age and environmental information disclosure, Simona and Veronika (2020). The result of this study is however not in agreement with the findings of Zaid (2013), Zaid and Nasiri (2018), Onyali and Okafor (2018).

\section{Conclusions}

The data analysis reveals the findings of the study, which were discussed. In view of this, we summarize the findings from the study as follows.

i. Total assets are positively and significantly related to the company social obligation of the listed gas and petroleum firms in Nigeria.

ii. Total sales are positively and significantly associated with the enterprise social commitment of the listed oil-and-gas firms in Nigeria.

iii. Financial leverage positively and insignificantly influences the business social obligation of the listed fossil oil firms in Nigeria. 

Nigeria

iv. Firm age negatively and insignificantly affects corporate public commitment of the listed fossil oil and gasoline firms in Nigeria.

In the light of the findings of the study, we concluded that total assets and total sales of the firms positively and significantly affect the corporate social responsibility of the firms. We also conclude that financial leverage positively and insignificantly affects the corporate social responsibility of the firms. Finally, firm age negatively and insignificantly affects the corporate social responsibility of the firms.

Based on the findings of the study, we recommend the following for possible implementation by the firm managers of oil and gas firms in Nigeria:

i. The managers should invest in assets especially long-term assets that will yield future streams of returns for their firms. Investment in assets improves production and promotes the corporate social responsibility performance of the firms.

ii. The firms should also promote their sales through various product promotion channels as total products boast firm profitability and promote corporate social responsibility of the firms.

iii. The firm managers should also increase the proportion of debts in their firms' capital structure. Financial leverage as could be seen from the findings of the study increase profitability and return for shareholders and also boast corporate social responsibility of the firms.

iv. The study demonstrated that firm age negatively affects the corporate social responsibility of the firms. In view of this, we recommend that firm managers should use a modern approach while implementing their corporate social responsibility programs.

\section{Acknowledgments}

The authors, Rapheal Oluchukwu Ugbor, Prof Oliver Ike Inyiama, Dr Cordelia Omodero and Dr Ethel Chinakpude Inyiama, thank the anonymous reviewers immensely and the journal editor for their valuable contributions. The contributions made the work better and acceptable for publication.

\section{Funding}

There was no receipt of a specific grant from any not-for-profit organizations, funding agency in the public sector of the economy, or the commercial sector.

\section{Author Contributions}

Rapheal Oluchukwu Ugbor and Prof Oliver Ike Inyiama conceived the study and formulated the research title. Rapheal Oluchukwu Ugbor, Dr. Cordelia Omodero and Dr. Ethel Chinakpude Inyiama were responsible for the design and development of 
Ugbor, R.O., Inyiama, O.I., Omodero, C.O., Inyiama, E.C., (2021)

Enterprise Financial Characteristics and Corporate Social Responsibility Costs of Oil and Gas Businesses in Nigeria

the research method which included data collection and analysis. Interpretation of the research outcome and literature review was done by Rapheal Oluchukwu Ugbor and Prof Oliver Ike Inyiama.

\section{Disclosure Statement}

The authors, Rapheal Oluchukwu Ugbor, Prof Oliver Ike Inyiama, Dr. Cordelia Omodero, and Dr. Ethel Chinakpude Inyiama, have not any competing financial, professional, or personal interests from other parties.

\section{References}

1. Alodia, I., Atmadja, A.S., (2018). The effect of firm characteristics and corporate governance on corporate social responsibility and future firm performance. Open Access Journal (MDPI), 5(3), 1-10.

2. Asimiea, A., Omokhua, G., (2013). Environmental impact of illegal refineries on the vegetation of the Niger Delta, Nigeria. European Journal of Business and Social Science, 4 (8), 14-30.

3. Asher, C.C., Mahoney, J.M., Mahoney, J.T., (2005). Towards a property rights foundation for a stakeholder theory of the firm. Journal of Management and Governance 9(1), 5-32.

4. Chang, Y., Gomes, J.F., Schorfheide, F., (2002). Learning-by-doing as a propagation mechanism. American Economic Review, 2(9), 1498-1520.

5. Enekwe, C. I., Agu C. I., Eziedo. K. N., (2014). Effect of financial leverage on financial performance: Evidence of quoted Pharmaceutical companies in Nigeria. IOSR Journal of Economics and Finance, 5(3), 17-25.

6. Fahimeh, Z., Shokat, B., (2015). Relationship between financial characteristics of companies in Cement Industry and their stock returns in Tehran Stock Exchange. Research Journal of Recent Sciences 4(8), 77-83.

7. Gitzmann, N., (2008). Legal personality of the corporate and international criminal law: Globalization, corporate human rights abuse and the one statute. Queensland Law Student Review, 1(1), 36-54.

8. Hassan, N.S.M., (2014). Investigating the impact of firm characteristics on the risk disclosure quality. International Journal of Business and Social Science 5(9), 109-119.

9. HeaJeong, H., Youngchan, K., (2020). The impact of firm age on corporate social responsibility. Paper from the $49^{\text {th }}$ Annual EMAC Conference, Budapest, May 26-29, 2020. 10. Kaoje, A. N., Auwal, B.N., (2020). Effect of sales and firm size on sustainability reporting practice of Oil and Gas companies in Nigeria. Journal of Research in Business and Management, 8(1), 1-8.

11. Karakteristikleri, F., Hilesi, M., Yaklaşım, C. D., (2016). Firm characteristics and accounting fraud: a multivariate approach. Journal of Accounting, Finance and Auditing Studies; 2(2), 128 - 144.

160 S sciendo Journal of Legal Studies Volume 28 Issue 42/2021

ISSN 2457-9017; Online ISSN 2392-7054.

Web: publicatii.uvvg.ro/index.php/jls. Pages $142-162$ 
Ugbor, R.O., Inyiama, O.I., Omodero, C.O., Inyiama, E.C., (2021)

Enterprise Financial Characteristics and Corporate Social Responsibility Costs of Oil and Gas Businesses in Nigeria

12. Kartiningsih, D., (2020). The consequence of firm attributes to the financial performance of food and beverages companies listed in Indonesia Stock Exchange. International Journal of Business, Economics and Law, 22(1), 69-76.

13. Kennon, J., (2017). Total sales revenue https://www.thebalance.com/total-revenue-ortotal-sales-357593.

14. Kokemuller, N., (2016). Importance of sales revenue to a firm. https://yourbusiness.azcentral.com/importance-revenue-10650.html.

15. Lawal, B., (2011). Board dynamics and corporate performance: Review of literature and Empirical Challenges. International Journal of Economics and Finance 4(1), 108-19.

16. Letza, S., Sun, X., Kirkbride, J., (2004). Shareholding Vs Stake holding: a critical review of corporate governance - corporate governance: An International Review 12(3), 242-262.

17. Maggina A., Tsaklanganos, A., (2012). Asset growth and firm performance Evidence From Greece. The International Journal of Business and Finance Research 6(2). 25-32.

18. Malarvizhi, P., and Yadav, S. (2008). Corporate environmental reporting on the internet. An insight into Indian practices. The annual convention of the strategic management forum. 19. Meric, I., Gong, L., Chaganti, R., Meric, G., (2012). A Comparison of the financial characteristics of U.S. and Japanese electrical and electronics equipment manufacturing firms. Southwest Business and Economics Journal8 (2), 75-83.

20. Mgeni, T.O., Nayak, P., (2016). Impact of structural firm characteristics on business performance of SMEs: Evidence from agribusiness firms in Dares Salaam. Tanzania Journal of Business Management, 6(5), 25-31.

21. Ojewumi, M.E., Okeniyi, J.O., Okeniyi, E.T., Ikotun, J.O., Ejemen, V.A., Akinlabi, E.T., (2018). Bioremediation: Data on biologically-mediated remediation of crude oil (Escravos Light) polluted soil using Aspergillus Niger. Chem. Data Collect. 17-18, 196-204.

22. Ojo, A.S., (2012). Effect of financial leverage on corporate performance of some selected companies in Nigeria. Canadian Social Science Journal, 8(1), 85-91.

23. Onyali, C. I., Okafor, T. G., (2018). Firm attributes and corporate environmental performance: Evidence from quoted industrial firms on Nigerian Stock Exchange. Scholars Journal of Economics, Business and Management; 5(2), 854 - 863.

24. Onyali, C. I., Okerekeoti, C. U., Uchegbu, C. U., (2020). Assessment of the effective factors of social responsibility disclosure of listed consumer goods firms on Nigerian Stock Exchange. International Journal of Innovative Finance and Economics Research, 8(2), 126133.

25. Owolabi, S. A., Obida, S. S., (2012). Business Management Dynamics, 12(2), 10-25.

26. Padachi, K., (2006). Trends in working capital management and its impact on firms' performance: An analysis of Mauritian small manufacturing firms. International review of business research papers; 2(2), 45 - 58.

27. Peterson R.H., (2002). Accounting for fixed assets (second edition). New York: John Wiley \& Sons, Inc.

28. Rehman, S.S.F., (2013). Relationship between financial leverage and financial performance: empirical evidence of listed sugar companies of Pakistan. Global Journal of Management and Business Research Finance, 13(8), 32-40. 
Ugbor, R.O., Inyiama, O.I., Omodero, C.O., Inyiama, E.C., (2021)

Enterprise Financial Characteristics and Corporate Social Responsibility Costs of Oil and Gas Businesses in Nigeria

29. Sam, K., Zabbey, N., (2018). Contaminated land and wetland remediation in Nigeria: opportunities for sustainable livelihood creation. Social and environmental Journal, 639(6), $1560-1573$.

30. Shuaibu, K., (2020). Firm characteristics and environmental disclosure quality of listed cement companies in Nigeria. African Scholar Journal of Mgt. Science and Entrepreneurship, 18(7), 105-118.

31. Shumway, T., (2001). Forecasting bankruptcy more accurately: A simple hazard model. Journal of Business, 74(1), 101-124.

32. Simona, C., Veronika, H., (2020). Firm characteristics and corporate social responsibility: The Case of Czech Transportation and Storage Industry. Open Access Journal (MDPI); 3(1), $1-12$.

33. Sinthupundaja, J., Chiadamrong, N., (2015). Investigation of Thai Manufacturing Public Firms' characteristics and financial strategies towards financial performance's improvement. Journal of Economics, Business and Management, 3(3), 331-337.

34. Singh, J. P., Pandey, S. (2008). Impact of working capital management in the profitability of Hindalco Industries Limited. Icfai University Journal of Financial Economics, 4(6), 6272.

35. Sloan, R., (2004). Balance Sheet Accounting. School of Management, Massachusetts Institute of Technology.

36. Sorensen, J.B., Stuart, T.E., (2000). Aging, Obsolescence, and Organizational Innovation. Administrative Science Quarterly, 1(45), 81-112.

37. Valipour, H., Moradi, J., Farsi, F.D., (2012). The impact of company characteristics on working capital management. Journal of Applied Finance \& Banking, 2(1), 106-125.

38. Vijayakumar, A., Devi, S.S., (2011). Growth and profitability in Indian Automobile Firms-An analysis. Journal for Bloomers of Research, 2(3), 168-177.

39. Uwalomwa, U., (2011). An empirical investigation of the association between firms' characteristics and corporate social disclosures in the Nigerian financial sector. Journal of Sustainable Development in Africa, 13(1), 60-74.

40. Yousra N. E., (2018). Impact of corporate characteristics on environmental information disclosure: An empirical study on the listed firms in Egypt. Journal of Business and Retail Management Research, 12(2), 232-241.

41.Zaid, M., Nasiri, A., (2018). The effects of firm characteristics on corporate social responsibility disclosure: Evidence from Palestine. Research Journal of Finance and Accounting, 9(13), 46-53.

42. Zaid, M., (2013). The effects of firm characteristics on corporate social responsibility disclosure: Evidence from Palestine. Research Journal of Finance and Accounting, 9(13), 25-37. 